\title{
農協・生協間の提携の諸形態之課題
}

——生活物資購買活動の場合について— 藤田教

\author{
Various Aspects and Problems of the Cooperation \\ between Agri-coop and Consumer's Coop
}

\author{
- A Case of Purchasing Activity of Foods and Daily Necessaries -
}

Oshie Fujita

At present, though the cooperation between agricultural cooperatives (abbreviated to AC) and consumer's cooperatives (abbreviated to $\mathrm{CC}$ ) is developing as direct trading of agriproducts, on the other hand, in purchasing activity of foods and daily necessaries, the competition between $\mathrm{AC}$ and $\mathrm{CC}$ is spreading.

The first thing to be done is to clarify the shapes of the cooperation which are possible to exist between $\mathrm{AC}$ and $\mathrm{CC}$, for the purpose of promoting cooperation between two.

I introduce the types of various cooperations between $\mathrm{AC}$ and $\mathrm{CC}$, from the two viewpo

\section{1. 課題と方法}

\section{(1) 課題の所在}

農協・生協間の提携は，協同組合原則が提起する 「協同組合運動の到達すべき理想像」として，実践者 と研究者が共々に待望・模索しているところであるが, その実態は極めて特異なものとなっている。

それは，提携推進が両系統全国中央からの理念先行 型活動になっていることと，事業提携が産值という特 定農畜産物の生産販売面に限定されていることとして 現れている。

そして，この特異性の故にか，今日の協同組合間提 携は一般的・日常的な提携への正常な発展が出来ない ままに一種の閉塞的状況に陥っているようにさえみら れる1!

特に, 後者の特徴である「産直限定の提携活動」は, 農協の存在を「消費者へ安全な農畜産物を供給する農 業者の組合」とのみ見る偏った状況を生み出し，結果 的にではあるが，農協が生活面事業等多種の事業を総 合兼営し，多様な農業者（同時に生活者）の全てを網 羅的に組合員とした上に，地域内住民をむ組合員（准 ints: one can be found in the methods of purchasing activity; the other in the multiplex charactaristics of cooperatives.

I then propose that in the first viewpoint the shapes of the cooperation between $\mathrm{AC}$ and $\mathrm{CC}$ can be divided to four types, and in the second viewpoint the various cooperations between them can be divided to three types.

Finally, in relation to these types I propose to systematize the problems which we must to recognize and conquer in the developing process of the cooperation between $\mathrm{AC}$ and $\mathrm{CC}$.

組合員)ないし随時の利用者 (員外者) としている特 異な協同組合であることを全く見失わせることになっ ている。

それは，実践的には，関係者が，産直以外の事業， 特に生活物資購買事業における農協・生協間の競合的 状態を默過したり，研究者の協同組合間提携に関する 理論的・実証的研究の殆どが産直ないし食料・農業対 策面での提携研究に終始して，農協・生協間提携の一 般的体系的研究が未着手のままになるなどの状況となっ ている ${ }^{2)}$.

以上の状況をみる時，農協・生協間提携の実践理論 的研究課題は, 提携推進活動の二つの特徴, すなわち 「全国中央からの理念先行型提携推進の限界性」と 「総合農協の特質が欠落した提携の産直への偏在化」 を統一的に解明・対策することにあると考えられる.

そして，そのためには，その基礎となる「農協・生 協間の提携之競合の存在形態と克服課題」の解明が急 かれ，本稿の中心課題とするところである。

\section{(2) 方法の概要}

本稿では，第 1 に，組合員の協同活動を基本とする 協同組合事業観に立って，農協と生協の生活物資購買 
活動を主体にした提携と競合を体系的に整理し，「農 協・生協間の提携之競合の存在形態」を解明する。

ついで第 2 に,「提携・競合の現状と特質」を，第 1 で解明した提携の存在形態を基に, 先進事例調查と アンケート調查の結果から考察・分析する ${ }^{3}$.

そして，第 3 に,「農協・生協間の提携化の契機之 克服課題」の解明を, 第 $1 \sim 2$ の考察と, 前掲のアン ケート調査の提言を基に試みる。

\section{2、農協・生協間の提携と競合の存在形態}

\section{（1）存在形龍整理の二つの視点}

提携・競合の存在形態の把握には協同組合の基本的 性格から次の 2 視点が必要である。

第 1 の視点は，市場活動面における存在形態，つま り資本主義市場経済における農協・生協の事業活動 （組合員の協同活動）の態様としての把握・整理であ $3^{4}$.

ついで第 2 の視点は, 協同組合の多側面ごとの存在 形態，つまり協同組合間の提携・競合が協同組合の多 面的性格を通じて現出する態様の把握・整理である ${ }^{5}$.

これは，事例的に捉えられる提携・競合の現象形態 と一面で共通するあのではあるが，協同組合の多面的 性格に則して，特に総合体系化するあのである。

\section{（2）市場活動面における存在形態}

1）市場活動面における提携の類型区分

市場活動面における提携の存在形態は，資本主義市 場に対する考え方，つまり提携の目的によって以下の 四つの場合に区分される。

(1)市場活動を全面的に拒否して，別個に非市場性の使 用価値の創出を指向する場合.

(2)市場活動を限定的に是認して，独自商品による差別 的市場の形成を指向する場合。

(3)市場活動を一般的に是認して，そこでの競争力の向 上を指向する場合。

(4)市場活動に内在する不公正性等に着目し，その防止・ 是正活動を指向する場合.

そして，この四つの場合を基本に，農協・生協間の 提携の存在形態を整理すると，図一1「市場活動面に おける農協・生協間の提携と競合の類型区分」となる。

なお，付加的に「第 5 の提携タイプ」を位置づける のは，協同の理念が実践活動の動態的過程を通じて形 成されると同時に, 協同組合の対内組織活動＝教育活 動によって形成されるという協同活動の基本的性格が この提携活動においても存在し, 提携活動を内側から 基礎づける教育活動面の提携活動が必須となるためで
ある6).

2）市場活動面における競合の類型区分

市場活動面における「競合の存在形態」は，「提携 の存在形態」が資本主義市場に対する対応姿勢自体に よって領域区分されるのとは異なり，提携の 4 類型の 領域区分を基本に，そこに生じる農協・生協間の競争 的状態として間接的受動的に把握される。

すなわち，協同組合間の競合の存在形態は図 1 の右 側部分に示す類型区分となる。

この場合，まず，第1タイプの提携（非商品創出型） の反対物として発生する農協・生協間の競争的状態は, その提携の独自性から実体的には把握できない，

したがって，競合のタイプは，第 2 タイプの提携 （独自商品形成型）の領域において発生する第 1 夕イ プの競合（組織摩擦的競合）と，第 3 タイプの提携 （費用低隇追求型）の領域において発生する第 2 タイ プの競合（市場競争的競合）の二つが主体になる。

なお，第 4 タイプの提携（市場是正活動型）の領域 において発生する第 3 タイプの競合（路線対立的競合） は可能性としては一応想定されるが，第 2 ・第 3 夕イ プの競合のように具体的事業として現れないために， 関係者には競合として特に認識されない。

3）提携・競合における類型間の相互関係 (1)提携における類型間の相互関係

了。第 4 の市場是正活動型提携は，その性格から第2。 第 3 の提携夕イプと直接的に連動する関係にあり, 一方, 第 1 の非商品創出型とは間接的な形で連動す る.

1. 第 1 の非商品創出型提携之第 2 ・第 3 の提携夕イ プの関係は非商品創出型の性格加々, 同一の農協・ 生協間での同時形成の可能性は一般的にそしいが; 同じ生協が異なった地域の農協を対象にして三つの 提携タイプを同時に形成する可能性が大きい.

ウ. 第 2 の独自商品形成型提携之第 3 の費用低減追求 型の関係は特定の対象品目や事業過程について選択 的に形成されるために，それらの多様な組み合わせ として存在する。

(2)競合に抒ける類型間の相互関係

了. 第 3 タイプの路線対立的競合はその基本的性格か ら第 1 ・第 2 タイプの競合と相互に連動して競合を 深化させる.

イ、第 1 タイプの組織摩擦的競合と第 2 タイプの市場 競争的競合の関係は相互に連動する関係にあって競 合を樑化させるが，その現れ方は農協・生協の性格 によって異なる，組織摩擦的競合が，主に生協・農 
図 1 「市場活動面」における農協・生協間の提携と競合の類型区分

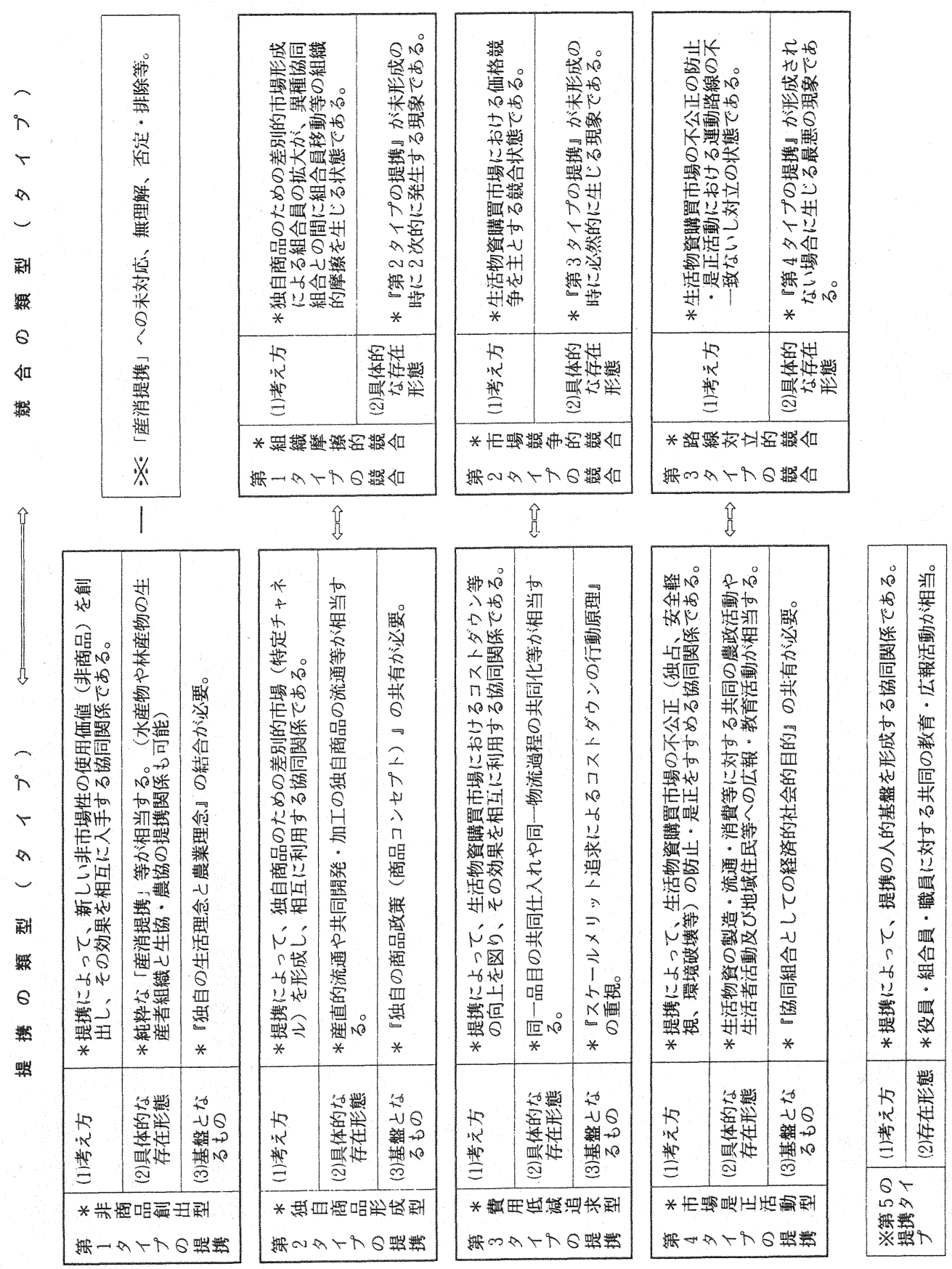


協の独自商品を基軸とする共同購入活動において, しかも，地方・農村圈に扔いて比較的明確な形で表 面化するのに対し，市場競争的競合は生協店舗と農 協の店舗ないし共同購入活動における一般品目にお いて生じる。

なお, 実態的には, 独自商品之一般品目が併せて取 扱われるために，第1タイプの組織摩擦的競合と第 2 タイプの市場競争的競合は重層した形をとり，さ らに第2 タイプの競合の殆どが大型量販店との競争 と複合しており, 競合のタイプ別把握は困難である.

（3）協同組合の組織・事業・経営面における提携と 競合

1 ）協同組合の 3 側面における提携の類型区分

協同組合の 3 側面における提携の存在形態は, まず 協同組合の組織面・事業面・経営面の 3 側面ごとの提 携の目的加ら枠的に三つに類型区分され，さらにこ れら 3 類型は組合員の協同活動の視点から，それぞれ 二つの局面を内包するすのとして把握される。

(1)組織面の提携一A. 制度 (法人) 相互間の提携, B. 組合員ないし組合員組織相互間の提携。(2)事業面 の提携一C．組合員の協同活動としての事業相互間の 提携, D. 協同組合が営む事業相互間の提携. (3)経営 面の提携一E．事業を営む協同組合経営相互間の提携, F．協同会社等別法人を起業する協同組合経営相互間 の提携。

この 3 類型と 2 局面に立って整理すると, 協同組合 の 3 側面における提携と競合は図一 2 「協同組合の 3 側面における農協・生協間の提携と競合の類型区分」 となる。

なお，図一 2 には，3 類型がそれぞれ内包する 2 局 面を符号 A〜Fで位置づけている。

2) 協同組合の 3 側面における提携の内部構造

これら三つの提携類型においては, 組合員が事業面 の利用効果を追求する「事業面の提携」が直接的且つ 基本的提携に位置し，組織面の提携之経営面の提携か それぞれの性格において「事業面の提携」を支持・補 完する形で両側に位置する内部構造となっている。

この基本的関係は，3 類型単位の比較では必ずしも 明瞭ではないが, 図一2 の A F Fレ゙ルにおける相互 関係にまで立ち入って考察すると明確な形で把握でき る.

すなわち，事業面の提携「C．組合員の協同活動之 しての事業相互間の提携」が組織面の提携「B．組合 員ないし組合員組織相互間の提携」之相互連動の関係 （三で囲む）にあり，そして，むう一方で，事業面
の提携「D，協同組合が営む事業相互間の提携」が経 営面の提携「E。事業を営む協同組合経営相互間の提 携」之相互連動の関係にある。

また，同時に事業面提携の内部では「CとD」が, 組織面提携の内部では「BとA」が, 経営面提携の内 部では「EとF」が，それぞれに，『枠組みと実質の 対応関係』として結びついていて，全体的に $\mathrm{A}$ 加ら $\mathrm{F}$ レベルに至る提携活動の連鎖が形成されている。

それは多重連鎖構造とす呼べるすのであって，提携 活動は各レベルごとに形成される小さな提携活動の相 互連動をもとにして動態的に発展する構造となってい る.

したがって，この多重連鎖構造を理解しないで，提 携を単に $\mathrm{A}$ や Fレベルの活動として部分的局面的に捉 えて推進するたけでは提携の本格的な進展にはなりが たい。

3) 協同組合の 3 側面における競合の類型区分 協同組合の 3 側面における競合の存在形態は，組織 面・事業面・経営面という三つの競合類型とそれぞれ が内包する二つの局面によって整理すると, 図 2 の右 側部分となる。

これら 3 競合類型間の内部構造は提携の場合に相似し ており、それは，組織面の競合が単独で生じるよりも 事業面の競合を媒介にして生じる場合が多いこと，ま た，事業面の競合が図 2 の〔c = b の関係のように， 組織面の競合として初めて表面化すること，さらには， 経営面の競合が通常直接的には認識されず, 図 2 の $\lceil\mathrm{d}=\mathrm{e} 〕$ の関係のように，事業面や組織面の競合を 通じて間接的に生じること等に現れている。

4) 両視点による提携類型の相互関係

ここで,これまでに考察した「市場活動面」視点に よる提携類型之「協同組合の 3 側面」視点による提携 類型の相互関係をみると，それは，図一 3 「両視点に よる提携類型の相互関係」のように整理できる.

それは提携の目的（発揮機能）に応じた提携の態様 (現出形態) の存在を示している。

なお，このことは，競合類型についても同様に考察 が必要であるが, 基本的には，提携類型の場合に類似 するあのであり，記述は省略する。

\section{3. 提携・競合の現状と特質}

\section{(1) 先進提携事例の類型亡概要}

生活物資購買活動に预ける農協・生協間の提携につ いて今のところ全国的な組織的実態調查が存在しない。 そこで, 前揭のアンケート調査と先進組合調查の結 
図 3 両視点による提携類型の相互関係

\begin{tabular}{|c|c|c|c|c|c|}
\hline & \multicolumn{4}{|c|}{ 「市場活動面」における提携類型 } \\
\hline & & $\begin{array}{l}\text { 非商品創 } \\
\text { 出型 }\end{array}$ & $\begin{array}{l}\text { 独自商品 } \\
\text { 形成型 }\end{array}$ & $\begin{array}{l}\text { 費用低減 } \\
\text { 追求型 }\end{array}$ & $\begin{array}{l}\text { 市場是正 } \\
\text { 活動型 }\end{array}$ \\
\hline \multirow{3}{*}{ 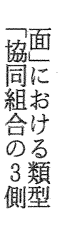 } & 組織面の提携 & $\begin{array}{l}\text { (O) } \\
\text { (B) }\end{array}$ & $\begin{array}{c}0 \\
(B-A)\end{array}$ & & $\begin{array}{l}\text { (?) } \\
\text { (A) }\end{array}$ \\
\hline & 事業面の提携 & $\begin{array}{l}\text { (a) } \\
\text { (C) }\end{array}$ & $\begin{array}{c}\text { (C) } \\
(C-D)\end{array}$ & $\begin{array}{c}0 \\
\text { (D) }\end{array}$ & \\
\hline & 経営面の提携 & & & $\begin{array}{c}(\mathrm{C}) \\
(\mathrm{E}-\mathrm{F})\end{array}$ & \\
\hline
\end{tabular}

(注)(1) 図は，各視点における「提携類型」が生起する組み合わせ を示し，そのうち@印は中心的な関係を示す。

(2) A-Fは，類型内の主な局面(図 2 に表示)を示す。

果汃ら，提携の現状と特質をみると，以下の 4 事例の ようになっている。

\section{1) 事例No. 1}

(1)提携の類型は，市場活動面に扔ける第2タイプ（独 自商品形成型）を基本に，第 3 タイプ（費用低隇追 求型）の性格を併存し，あう一面では県段階連合組 織間の「事業・経営面の提携（図2 2 D E) であ り, 事例中, 厳密な意味での唯一の提携事例である。 また，この提携が首都圈の某県での「提携協議会」 活動，つまり組織面の提携（図2のA）を基盤にし て形成されていることに特色がある。

(2)提携の内容は，県産小麦によるめん類等の共同開発。 共同加工（分担加工，共同委託加工を含む）したも のを農協，生協がそれぞれ組合員に供給する。

2) 事例№. 2

(1)提携の類型は，純粋な独自商品形成型提携ではなく て, その実践的な変形方式（参加利用的提携関係） であり，単位農協の主体性による「事業面の提携 （図 2 の B C )」の性格が強い.

(2)提携の内容は，コープ商品等生協の独自商品を農協 が受け入れて組合員に供給するあので，当該農協は 生協連合組織の会員になっている東北地区某県等の 少数事例である。

3) 事例N No. 3

(1)提携の類型は，本来，農協の販売加工之生協の提携 で生活物資購買活動面の提携に該当しないが，生協 と農協の購買量の占める割合が大きい場合は, 実質 的に共同加工面に打引る費用低減追求型に独自商品 形成型の性格を加えた提携に転化・発展する。

なお，この二つの提携関係が結合した「トライアン グル状の提携方式」は，漁協・生協・農協間の提携 による水産加工品，森林組合・生協・農協間の提携
による林産加工品等においてあ形成されるあのであ る.

(2)提携の内容は，農協が開発・加工した農畜産物加工 品を農協と生協がそれぞれ組合員に供給するすので, 三者による計画的な商品共同開発・加工・利用には 至っていない。

4) 事例No. 4

(1)提携の類型は，原料供給者である農協の連合組織が 生協の食品加工場に経営参加する「経営面の提携 (図 2 の F)」で, 費用低減追求型提携の性格が強い が, 厳密には生活物資購買活動面の提携には該当し ない，いわば「間接的・多面的提携」に相当する。 なお，生活物資購買における提携が『信用・共済・ 厚生・生活文化・地域開発面』の事業を含めた農協 と生協の「ネットワーク的提携関係」の一環として 形成されることも重要である。

(2)提携の内容は，阪神圈の大生協之農協全国連合会が 食品加工の共同会社を設立し製品を生協が組合員に 供給するもので，その製品を会員農協が利用するに は至っていない。

\section{（2）生活物資購買活動における競合の特質}

次に，生活物資購買活動における農協・生協間の競 合実態について，前揭のアンケート調査の結果によれ ば，以下の特徴点が拙出できる ${ }^{7)}$.

(1)農協関係者には「競合」についての事実認識ないし 被害者的意識が多分に存在するのに対して，生協関 係者には「競合」についての事実認識自体が殆どな いこと。

(2)農協の生活購買活動と生協活動の並立の状況が全国 的にあ相当程度存在すること.

(3)(2)の状況で, 特に生協・農協の共同購買活動の並立 とその結果としての競合,つまり組織摩擦的競合や 
組織面の競合（図 2 の $\mathrm{b} \sim \mathrm{c}$ レベル）が比較的鮮明 化していること.

(4)大都市圈等都市化地域では競合が殆ど問題にならず, 地方圈で問題化していること。

(5)農協・生協の系統事業方式が、提携未形成の反面之 しての競合となっていること。

(6)農協, 生協の双方に具体的事業レベルでの交流・協 議等の活動実績がないこと。

\section{4. 農協・生協間の提携化の契機と克服課題}

（1）市場活動面における対応方策と提携の展開方向

1）市場活動面における対応方策の体系

— 提携化の契機 —

組合員の協同活動を基本とする事業観に立って，協 同組合の「市場活動面における対応方策」を整理する 之，図一４「生活物資購買活動における市場活動面の 対応方策之提携展開の体系」の図側「市場活動面にお ける対応方策と提携展開の体系」の部分となる。

それは，組合員の「期待する生活物資・サービスの 効果的な入手」という目的に対する対応方策の体系, つまり符号(1)〜@に示す諸方策として把握される。

まず第 1 段階として, (1)効果的な市場競争力の追求, (2)市場の不公正の是正・防止の追求，(3)食物の市場流 通の否定，の三つの方策が基本的な枠組みを形成する。

ついで，対応方策の中核である(1)効果的な市場競争 力の追求は, (4)商品の独自差別化の追求, (5)スケール・ メリットの追求，の2方向の方策に具体化されるとと あに，(5)の方策に関連して，(6)新事業方式・ノウハウ の追求が必然化してきて，併せて，(4)と(5)および(6)の 三つの方向の対応方策が第 2 段階の枠組となる。

他方，(2)市場の不公正の是正・防止の追求は(7)農政 活動・生活者活動の展開として, (3)食物の市場流通の 否定は(8)産直〜独自経路の開拓として，それぞれ具体 化される。

この対応方策の基本的枠組みは, (4)と(5)の方策が先 に設定した第 2 の独自商品形成型提携之第 3 の費用低 減追求型提携に照応し，(7) と(8)の方策が第 4 の市場是 正活動型提携之第 1 の非商品創出型提携に照応する関 係として把握される。

2）個別対応方策之提携展開の方向

このような基本的枠組みにおける個別対応方策と提 携化の関係は，(4)商品の独自差別化の追求が，(9)組合 員参画による独自商品の形成化之110経営ベースでの独 自商品の開発化という 2 方向に分化し，さらに，その うちの(9)の方策が，13事業活動之組合員組織活動の一
体化としてょり純化するか，(14)異種協同組合の組合員 組織間の提携化として地域全体により一般化するかの 選択関係を形成する。

なお，(9)の方策は，上記の 2 方向に加え(8)産直と相 互に深く影響し合う関係にある。

この方策パターンは，共同購入活動主体の生協の成 立・発展に典型的にみられるととあに，(14の方策には， 提携事例で考察した「参加利用的提携関係」ないし 「トライアングル状の提携方式」が近似的に照応して いる.

また，一方(10の方策は，(11)単位組合のエリア拡大化・ 合併化と (12同種協同組合間の提携・連合組織化の 2 方 向に分化するが，これまで農協は後者を全面的に指向 してきている。

ついで，あう一方の柱である(5)スケール・メリット の追求は，(11単位組合のエリア拡大化・合併化と(12)同 種協同組合間の提携・連合組織化の 2 方向を指向する。

そして，それらは結果的に，先の10経営ベースでの 独自商品の開発化においてとられる二つの方策之重な り合い, 協同組合の事業・経営力の強化となって具現 する。

これまで，生協では(11)の方策を主に(12)の方策が併せ て指向されたのに対し, 行政依存の事業展開をしてき た農協では(12)の方策（系統農協体制化）が全面的に指 向されてきていた。

さらに近年では，(12)の方策が，(6)新事業方式・ノウ 八ウの追求の方策との関連加ら (16)同種協同組合間での 事業のシステム的展開へと变化・拡充してきている.

この方策パターンは, 農協でのAコープチェーン, 生協でのブロック事業連合方式の形成として典型的に 現れてきている。

一方，(15)異種協同組合 (連合組織) 間の提携化は, (4)商品の独自差別化の追求と(5)スケール・メリットの 追求の 2 方向抢よび単位組合段階での提携化之連合組 織段階での提携化の 2 段階の組み合わせとして，ほぼ 五つの提携化経路が想定される。

しかし，その実態は，提携化吕停滞する中で，農協・ 生協とむに(11)の方策とそれを基盤とする(16)の方策の充 実が基本となっており，さらには，その路線の完成。 高度化の形態として，18同種協同組合間での協同会社 の形成が農協・生協それぞれに指向されつつあり，特 に農協ではそれが全国連合組織から県段階連合組織へ と波及しつつある。

それは，事業のシステム的展開のためのノウハウの 追求を軸にして，⑳営利企業之の提携（業務提携～共 
図 4 生活物資購買活動における市場活動面の対応方策と提携展開の体系

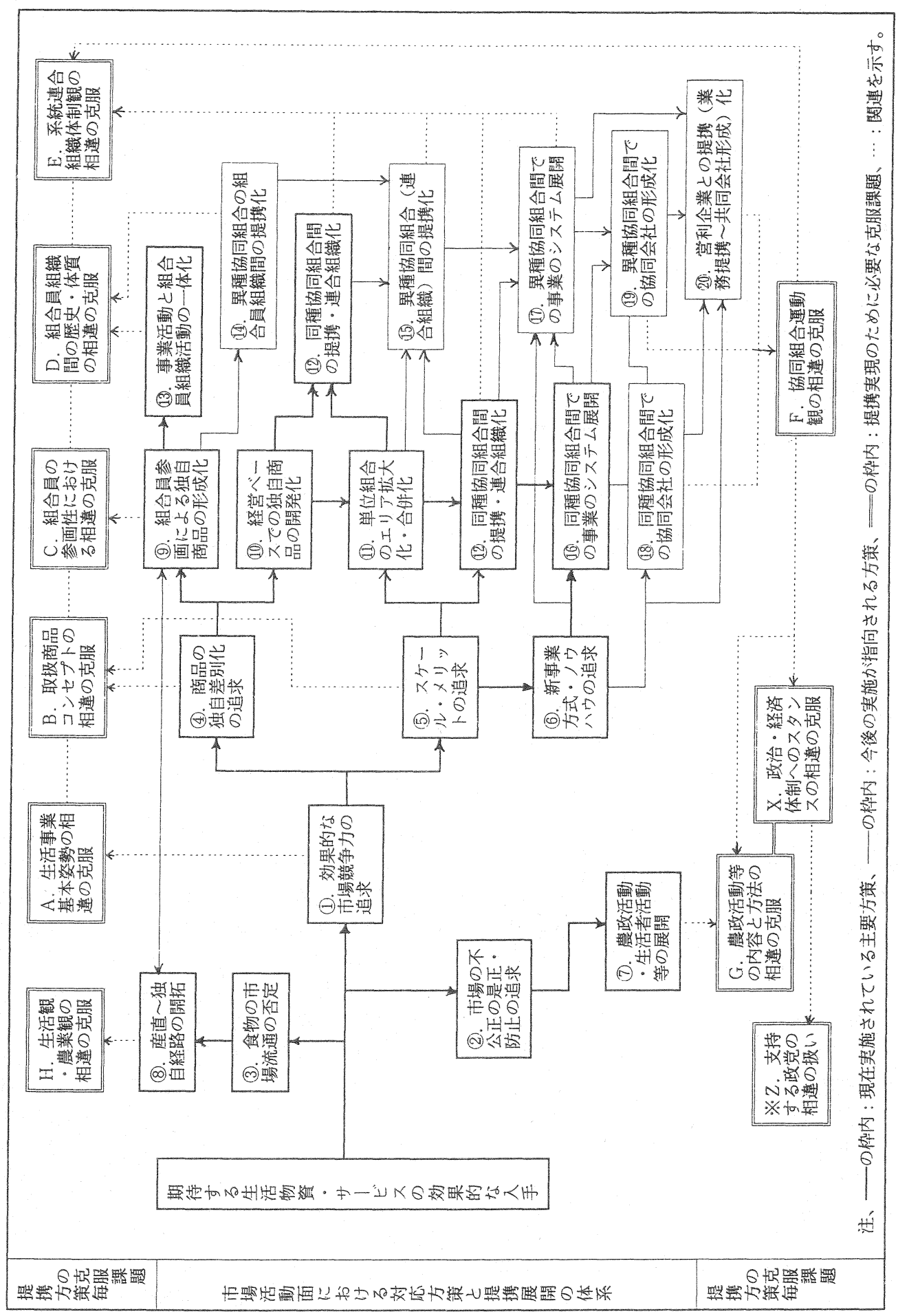


同会社形成）化を指向する可能性すら多分に驿んでい る。

なお，この過程で(17)異種協同組合間での事業のシス テム的展開が指向されたり，その延長としての19異種 協同組合間での協同会社の形成,さらには農協·生協提 携の下での20の方策，等はもとより多分に想定される.

しかし，大型流通資本への対抗策として(5)スケール。 メリットの追求ないし(6)新事業方式・ノウハウの追求 を指向する場合においては，一般的にみて前者の提携 経路 (12) $\rightarrow$ (16) $\rightarrow$ (18) $\rightarrow$ (20) ) が先行して選択される公算が 大きいとみられる。

そして，このような対応方策の選択は，農協・生協 間に市場競争的競合のみを強め，併せて，同種協同組 合内では，(4)の方策を中核に(9)，(13)，(14)等の方策に協 同組合事業の特質を見出す組合との間に大きな運動路 線上の相違を生じることになる。

\section{(2) 提携展開の克服課題・条件}

\section{1)「提携方策」毎の克服課題・条件}

市場活動面における対応方策と提携展開の体系に立っ て提携化のための克服課題（それはもう一面からみる と「提携化の条件」であるが）を整理したものが，前 出の図一 4 の図側「提携方策毎の克服課題」の部分で ある。

それは，基本的には先の対応方策（符号(1)～(20）に 関連して存在する「農協・生協間の各種の相違」の克 服，つまり符号 $\mathrm{A}$ 〔生活事業基本姿勢の問題〕から符 号H〔生活観等の問題〕までに示す諸課題・条件の体 系として把握されよう。

そして，さらには，わが国の農協と生協の形成・発 展の歴史的過程における行政との特殊な関係から，符 号X〔政治・経済体制へのスタンスの問題〕ないし符 号Ｚ〔支持政党の問題〕の課題を屯含めて捉えること が必要亡考える。

また，A〜HおよびX（～Z）の克服課題は，基礎 的 - 一般的課題加 22 次的ないし 3 次的 - 個別課題へ と立体的構造をなして存在する。但し，本稿ではその 考察と体系化を省略して, 図一 4 に示す最す単純な単 線的相互関係として把握するに止める.

なお，A〜Zに示す「農協と生協間の相違」は，直 接的には，前述の農協・生協関係者に対するアンケー 卜調査における「産直提携の進展に比べ生活物資購買 活動面での提携事例が少ない理由」および「生活購買 活動における農協と生協との提携強化方策の提案」 （自由記入延べ44件）から導いたものである，以下， それぞれの要点を述べてみよう。
(1)A 〔生活事業基本姿勢の問題〕では，特に農協の生 活購買活動姿勢の不鮮明さと弱さ，根本的には農協 におけ生活事業の意義・目標についての実践理論欠 落の問題がある。

(2) B【商品コンセプトの問題〕では、コープ商品とA コープ商品や共同購入活動独自品目の相違ないし組 合員の商品に対する期待度の相違 ( $\mathrm{H}$ とも関連) が ある。また，それに加えて組合員が参画と利用を通 じて独自品目を育てたというCとDの問題が重層す る.

(3)C〔組合員の参画性の問題〕では, 生協の班活動等 にみられる組合員の参画性と農協の実態との格差で ある。只，専門職員による経営べースの開発が進む と状況は変化する。

(4)D〔組合員組織の問題〕では，農協婦人部を典型と する農協組合員組織のむら社会的体質と生協の市民 社会的体質との相違である。只，若い世代層主体の 組織では問題が緩和されるが，根底にはわが国の夕 テ社会的性格があり，Eの問題も一部重層している。

(5) E〔系統連合組織観の問題〕では，単位農協の連合 組織への依存・彷属性（根源的には行政への従属。 依存性）が特に問題であるが，生協系統であ同様の 問題が存在し, 同種協同組合の連合組織体制の本質 が問われる課題である (制度面の問題は当然存在)。

(6) F [協同組合運動観の問題】では，A〜Eまでの相 違の基盤レベルでの相違であり，大型流通資本の攻 勢に詨する協同組合事業・経営の生さ残り方策とし て, 協同会社化加ら営利企業との提携化さえ指向す る経営姿勢の強まりをどうみるかが中心問題である.

(7) G [生活者活動の問題〕では，農協農政活動の業界 団体的性格，特に生活面課題への対応の弱さと生協 生活者活動の市民運動的性格との間に大きなギャッ プがある。この課題は，基本的にはXの課題と密着 し，実践面では，Zの問題と深く重層している。

8) H〔生活観等の問題〕では，産直は純粋であるだけ に限定的なものとなるが，市場流通的産直等のレベ ルで参加できる組合員をどれだけ拡大できるかが問 題となる。

2 ）克服課題への実践的対応

これら 8 課題への実践的対応の面においては，基本 的には，図一 4 下側のF〔協同組合運動観の問題〕が 上側の $\mathrm{A} \sim \mathrm{E}$ 等の基盤であるから優先的に取り組まな くてはならないという考え万に対し，A～E等の具体 的実践活動があってこそFも相互関連的に解決される とする考え方がある。 
一方，現実には，X〔政治・経済体制へのスタンス の問題〕ないし 題の相互関係について, 「農協・生協間提携の最大の 克服課題はX $(\sim Z)$ であって, その解決なくして提 携化は望めない」とする見方が底流的に存在して提携 を意識面で抑止している ${ }^{8)}$.

この問題は, 多様な地域の政治的社会的状況や組合 の形成・発展の歴史的状況を反映してその根本的解決 は容易ではない，従って，提携化の方策としては，こ れまでの図一 4 下側の克服課題重視の固定観念から脱 却して，まず，日常活動の積再重㸚によって同図上側 の克服課題の解決を図っていくことが望ましいであろ う.

例えば，Z〔支持政党の問題〕を,トップ会談によ る『政経分離を前提にした産直』として解決し，それ を糸口に提携を順次発展させて状況を実践的に改善し ている先進事例がある。このような対応方策の考元方 が提携化に対して新しい展望をもたらすのではないで あろうが?.

\section{5.むすび}

以上の考察を通じて，農協・生協間に生起し得る多 様な提携之競合の存在形態を，「市場活動面」と「協 同組合の 3 側面」の 2 視点加ら類型化し, 図 1, 図2, 図 3 に示すよう体系化した。しかし，その実践事例は， $「 3 」 て ゙$ 考察したように極めて少なく，提携化のため に克服すべき課題は「「４」で図４に整理したように 錯綜した因難なすのであった。

農協・生協間の提携問題は，その存在形態や克服課 題の究明を通じて明らかになったように，農協・生協 の活動理念・目的ないし事業の本質を改めて問うもの である。

そして，意義ある効果的な提携の形成は，農協・生 協がそれぞれ意義ある効果的な実体をもっていて初め て可能になる。従って，提携化は同時に農協・生協の 真の協同組合化への回帰という意義をすっている.

費用低減追求型提携が, 市場における「スケールメリッ 卜追求」埋没し, 組合員不在の協同組合経営生き残 りの戦略と化する場合は, 結果的に, 協同組合の企業 化と市場競争的競合を招来するのみになってしまう。 また，独自商品形成型提携等が，わが国の夕テ社会的 特質のままに同種協同組合組織発展の戦略之化する場 合は，結果的に，組織摩擦的競合等を激化させること になろう。

協同組合の本質から，多様な協同組合が同一地域に
成立して活動することは避けられず，それら協同組合 の画一的な提携化は望むべくあないが，それ故に，組 合員の新しい生活ニーズに立った事業（協同活動）の 展開過程において提携の契機があるならば積極的に対 応することの重要性が痛感される。

\section{《参考資料・文献 $>$}

1) 菅伸太郎「改めて協同組合間提携を省みて」『21世紀へ の新たな協同組合間提携の方向』第 1 章, 協同組合間提携 研究会, 1992。4, 参照.

2) (1)協同組合間提携推進事務局『協同組合間提携の戦略的 展望』時潮社, 1982, 参照。

(2)協同組合経営研究所編『協同組合間提携の理論と実践』 全国協同出版，1992，参照。

3) アンケート調查は協同組合間提携研究会（代表管伸太郎） が平成 3 年11月に実施。

(1)『生活購買活動における生協之の競合状況調查（各都道 府県中央会生活担当部門長宛 : 依頼47, 回答34) と(2)『生 協と農協の生活購買事業における提携の可能性（全国主要 地域購買生協宛 : 依頼79, 回答34)の 2 種類, 調查協力を得 るために会名，組合名は未公表とする、詳細は前揭 1 の報 告書参照,

4) 組合員の協同活動を基本とする協同組合事業観について は，藤田教「協同活動視点からみた総合農協事業の特質」 『協同組合研究』6-2, 日本協同組合学会, 1987, 参照。

5 ）協同組合の多面的性格については, 運動体・経営体の 2 側面区分と組織・事業・経営の 3 側面区分の二つの見解が 一般的であるが，3 側面区分については概念規定が必ずし も明確となっていないとの指摘がある。堌田佳昭「協同組 合の事業的特質之事業論的研究の課題」『農協運動の現代 的課題』I 部第 4 章, 全国協同出版，1992，参照。

6) 前揭の 4 参照.

7）藤田教「農協・生協間の事業競合の諸問題」前掲 1 の報 告書, 第 4 章 2 , 参照。

8) 甲斐武至「協同組合間提携のめざすもの」前揭 2-(2), $\mathrm{I}-1$, 参照.

9)「政経分離を前提とした提携事例」は，山形県経済農協 連と生活協同組合共立社によるあのであり，その事情は， 第12回日本協同組合学会大会ミニシンポジゥムの記録「地 域経済活性化，生活文化の創造をめざす協同組合の役割と 課題」の39 40頁, 第12回日本協同組合学会大会実行委員 会, 1993, 参照.

（篓者：元愛缓農協学園常任講師） 